\title{
Investigation of Genetic Diversity among Bread Wheat Cultivars (Triticum aestivum L.) Using SSR Markers
}

\author{
Reza Drikvand $^{1}$, Mohammad Reza Bihamta ${ }^{2}$, Goodarz Najafian ${ }^{3} \&$ Asa Ebrahimi ${ }^{1}$ \\ ${ }^{1}$ Department of Plant Breeding, Science and Research Branch, Islamic Azad University, Tehran, Iran \\ ${ }^{2}$ Department of Agronomy and Plant Breeding, University of Tehran, Iran \\ ${ }^{3}$ Cereal Chemistry and Technology Unit, Seed and Plant Improvement Institute, Karaj, Iran \\ Correspondence: Reza Drikvand, Department of Plant Breeding, Science and Research Branch, Islamic Azad \\ University, Tehran, Iran. E-mail: drikvand_f@yahoo.com
}

Received: October 9, 2012 Accepted: October 26, 2012 Online Published: December 13, 2012

doi:10.5539/jas.v5n1p122 URL: http://dx.doi.org/10.5539/jas.v5n1p122

\begin{abstract}
The present study was conducted to understand the genetic diversity of bread wheat's that grown in Iran, and to evaluate polymorphism information content (PIC) of some wheat SSR primers. Experiment was done in the genomics Laboratory in Islamic Azad University, Khorramabad branch, Iran in 2012. Ninety-two bread wheat varieties were assayed to study the genetic diversity and polymorphism based on forty whole-genome SSR markers. Eighty alleles were identified and 2 alleles per locus were detected. The majority of SSR markers showed a high level of polymorphism. PIC values ranged from 0.12 (XBARC 148) to 0.80 (XBARC 54), with an average of 0.59 per primer, which indicates that markers were highly informative. According to similarity matrix, genetic similarity value ranged from 0.17 to 0.88 . The lowest and highest genetic similarity were observed between 'Mihan' and 'Star' (No 31 and 57), 'Azadi' and 'Mahdavi' (No 4 and 6), respectively. Cluster analysis using the UPGMA method based on Jaccard coefficients was performed. Based on cluster analysis, 92 wheat cultivars were grouped in six clusters. Results indicated that Iranian grown wheat cultivars had high genetic diversity which could be exploited in wheat breeding programs.
\end{abstract}

Keywords: bread wheat, genetic diversity, PIC, SSR

\section{Introduction}

Common wheat Triticum aestivum L. $(2 \mathrm{n}=6 \mathrm{x}=42)$, belonging to the family Poaceae, which is considered the most diverse and important family of the plant kingdom, produces large edible grains and provides about one-half of humans' food calories and a large part of their nutrient requirements. The availability of genetic variability in wheat material is a pre-requisite for any breeding program aimed towards the improvement of wheat productivity. Wheat breeding through hybridization also requires the selection of diverse genotypes, irrespective of whether the end product is a pure line or a hybrid variety (Prasad et al., 2000). Loss of genetic diversity has become a problem, not only of the natural plant and animal population, but also agriculturally important species. Ancient cultivars or landraces and wild relatives of domesticated species are being lost as modern varieties become adopted by farmers. This had led to calls for genetic conservation of crop germplasm (Frankel \& Bennett, 1970). The use of molecular markers for the evaluation of genetic diversity is very common. Simple sequence repeats (SSRs) (Tautz et al., 1989) has been widely exploited in wheat due to its high level of polymorphisms, co-dominant inheritance and equal distribution in wheat genome (Roder et al., 1995; Parker et al., 2002). SSRs is more abundant, ubiquitous in presence, hypervariable in nature and has high polymorphic information content (Gupta et al., 1996). These markers have been used to characterize genetic diversity of wheat in many studies, including: Ijaz and Khan (2009) who investigated the genetic diversity of 63 bread wheat genotypes composed of 48 accessions and 15 cultivars, using 56 SSR markers. Cluster analysis based on microsatellite allelic diversity discriminated the accessions and cultivars into different clusters. Genetic diversity in 60 released hard red winter wheat cultivars were analyzed with 62 microsatellite markers in the Great Plains region of The United States. In that study, they found that genetic diversity gradually increased in cultivars released after the 1970s and cultivars released in the 1990s had the highest allelic richness. Cluster grouping gave close matches with pedigrees and with regional distribution of the cultivars (Prasad et al., 2009). Hai et al. (2007) using 52 SSR markers studied genetic diversity of 69 accessions of spring bread wheat and showed that the polymorphism index content value varied from 0.24 to 0.89 with an 
average of 0.68 . The highest PIC for all accessions was found in the B genome (0.71) as compared to the A (0.68) and D genomes (0.63). In addition, SSR markers has been used to study genetic diversity of wheat cultivars in Argentina (Manifesto et al., 2001), Egypt (Salem et al., 2008), France (Roussel et al., 2004), Iran (Eivazi et al., 2008; Mohammadi et al., 2009), US (Mahmood et al., 2004; Fufa et al., 2005; Chao et al., 2007), and Turkey (Akkaya \& Buyukunal-Bal, 2004; Altintas et al., 2008). However, genetic diversity of all bread wheat's that are cultivated in Iran, have not been evaluated by SSR markers. The aim of our study was evaluation of polymorphic information content (PIC) of 40 SSR markers, genetic variation among 92 bread wheat cultivars that are grown in Iran and to select parents to be used in development of high-yielding wheat cultivars in breeding programs.

\section{Materials and Methods}

\subsection{Plant Materials and DNA Extraction}

The experiment was conducted in the genomics Laboratory in Islamic Azad University, Khorramabad branch, Iran in 2012. Ninety-two bread wheat genotypes (Table 1) were employed that either have been cultivated previously or are under cultivation at present in different regions of Iran and used widely in wheat production as well. DNA was extracted from two-week old plants of each genotype following the protocol of Diversity Arrays Technology company (DArT) (http://www.diversityarrays.com). The quality of the extracted DNA was examined under $0.8 \%$ agarose gel electrophoresis. DNA concentration was estimated using Picodrop. The final DNA concentration of each template stock was adjusted to $50 \mathrm{ng} / \mu 1$.

\subsection{SSR Analysis}

Forty of SSR primers comprising 14 BARC (Song et al., 2005), 10 XGWM (Roder et al., 1998), 7 WMC (Gupta et al., 2002), 6 XCFD (Guyomarch et al., 2002) and 3 XCFA (Sourdille et al., 2001) were used in the present study. Primers were distributed on whole genome and selected from all 21 chromosomes of hexaploid wheat. The PCR was performed in a Thermal Cycler (Bio-Rad Model thermal cycler) in a volume of $15 \mu \mathrm{L}$ containing $3 \mu \mathrm{L}$ of DNA $(50 \mathrm{ng} / \mathrm{mL}$ ) and $12 \mu \mathrm{L}$ of the master mix that consisted of $7.8 \mu \mathrm{L}$ of ddH20, $1.5 \mu \mathrm{L}$ of 10X PCR buffer, $0.3 \mu \mathrm{L}$ of $100 \mathrm{mM} \mathrm{MgCl} 2,0.3 \mu \mathrm{L}$ of $10 \mathrm{mM}$ dNTPs, $0.5 \mu \mathrm{L}$ of each forward and reverse primer $(1 \mathrm{p} . \mathrm{m} / \mathrm{mL})$ and $0.1 \mu \mathrm{L}$ of Taq polymerase $(500 \mathrm{U} / \mathrm{mL})$. The amplification step was as follows: 1 cycle at $94^{\circ} \mathrm{C}$ for $4 \mathrm{~min}$, then 35 cycles comprising $94^{\circ} \mathrm{C}$ for $1 \mathrm{~min}$, annealing of primer at $50-60^{\circ} \mathrm{C}$ (depending on the primer) for $1 \mathrm{~min}$ and then extension at $72^{\circ} \mathrm{C}$ for $1 \mathrm{~min}$. The final extension was carried out at $72^{\circ} \mathrm{C}$ for $10 \mathrm{~min}$. The amplification products were electrophoresed on 3.5\% agarose gels (50\% Metaphor and 50\% LE agarose), and for staining, $3 \mu \mathrm{L}$ Gel Red and dye (the 1.5:1.5 ratio) was added to each sample. Photography was performed using the Bio-Red Gel Doc.

\subsection{Data Collection and Analysis}

Presence and absence of bands were scored as 1 and 0 , respectively. Genetic similarities were calculated using the Jacquard similarity coefficient (Jaccard, 1908), and dendrogram obtained by clustering according to the un-weighted pair group method with arithmetic average UPGMA algorism using the NTSYS-pc software version 2.02 (Rohlf, 1992). For the detection of alleles frequency Microsoft Excel software was used. Polymorphism information content (PIC) values were obtained using the formula developed by Anderson et al. (1993). $\mathrm{PIC}=1-\Sigma \mathrm{Pij}{ }^{2}$, where $\mathrm{P}_{\mathrm{ij}}$ is the frequency of $\mathrm{j}^{\text {th }}$ allele of $\mathrm{i}^{\text {th }}$ locus, summed across all the alleles for the locus over all genotypes.

\section{Results and Discussion}

\subsection{SSR Polymorphism}

In the present study 40 primers were used, each of primers detected two loci, A total of 80 alleles were identified. Majority of primers had high PIC and they identified high level of polymorphism. Therefore, these primers can be recommended to study genetic diversity and molecular mapping in bread wheat. The PIC-values, ranged from 0.12 for Xbarc148 to 0.80 for Xbarc54, with an average of 0.59 for all markers (Table 2).

This indicates that the markers were highly informative. Botstein et al. (1980) reported that PIC value $>0.5$ is considered as being highly informative marker while $0.5>\mathrm{PIC}>0.25$ is just informative marker, while PIC $\leq 0.25$ is a slightly informative marker. In previous studies, Landjeva1 et al. (2006), reported the PIC values in Bulgarian winter wheat ranged between 0.10-0.81. Bryan et al. (1997) found that PIC value with an average of 0.51 from 49 SSR primer pairs was isolated from hexaploid wheat genome. The genetic differentiation of 60 wheat cultivars selected for adaptation and end-use from Hungary, Austria, and German using 42 microsatellites showed an average PIC value of 0.57 (Stachel et al., 2000), that the results of the present study confirmed it. 
Table 1. Names of bread wheat used in the study (2012)

\begin{tabular}{|c|c|c|c|c|c|}
\hline No. & Name/ Identity & Growth type & No & Name/ Identity & Growth type \\
\hline 1 & Karaj-1 & Facultative & 47 & Morvarid & Spring \\
\hline 2 & Karaj-2 & Facultative & 48 & Gonbad & Spring \\
\hline 3 & Karaj-3 & Winter & 49 & Arvand & Spring \\
\hline 4 & Azadi & Spring & 50 & Chenab & Spring \\
\hline 5 & Ghods & Spring & 51 & Bayat & Spring \\
\hline 6 & Mahdavi & Facultative & 52 & Falat & Spring \\
\hline 7 & Niknejad & Spring & 53 & Heirmand & Spring \\
\hline 8 & Marvdasht & Spring & 54 & Darab-2 & Spring \\
\hline 9 & Pishtaz & Spring & 55 & Atrak & Spring \\
\hline 10 & Shiraz & Spring & 56 & Chamran & Spring \\
\hline 11 & Sepahan & Spring & 57 & Star & Spring \\
\hline 12 & Bahar & Spring & 58 & Dez & Spring \\
\hline 13 & Parsi & Spring & 59 & Vee/Nac & Spring \\
\hline 14 & Sivand & Spring & 60 & Line A & Spring \\
\hline 15 & M-85-7 & Spring & 61 & Aflak & Spring \\
\hline 16 & WS-82-9 & Spring & 62 & Baaz & Spring \\
\hline 17 & Sirvan & Spring & 63 & Shahpasand & Winter \\
\hline 18 & DN-11 & Spring & 64 & Omid & Winter \\
\hline 19 & Bezostaya & Winter & 65 & Roshan & Facultative/Spring \\
\hline 20 & Navid & Facultative/Winter & 66 & Tabassi & Facultative \\
\hline 21 & Alamout & Facultative/Winter & 67 & Sholleh & Spring \\
\hline 22 & Alvand & Facultative & 68 & Sorkhtokhm & Spring \\
\hline 23 & Zarin & Facultative & 69 & Adl & Facultative \\
\hline 24 & MV-17 & Winter & 70 & Sardari & Winter \\
\hline 25 & Gaspard & Winter & 71 & Azar-2 & Winter \\
\hline 26 & Gascogne & Winter & 72 & Zagross & Spring \\
\hline 27 & Soisson & Winter & 73 & Sabalan & Winter \\
\hline 28 & Shahriar & Winter & 74 & Sp.Bc of Roshan & Spring \\
\hline 29 & Tous & Winter & 75 & Wi. Bc of Roshan & Winter \\
\hline 30 & Pishgam & Facultative & 76 & Cross of Shahi & Winter \\
\hline 31 & Mihan & Winter & 77 & Maroon & Spring \\
\hline 32 & Oroom & Facultative & 78 & Kavir & Spring \\
\hline 33 & Zaree & Winter & 79 & Hamoon & Spring \\
\hline 34 & Inia & Spring & 80 & Bam & Spring \\
\hline 35 & Khazar-1 & Spring & 81 & Akbari & Spring \\
\hline 36 & Mughan-1 & Spring & 82 & Sistan & Spring \\
\hline 37 & Mughan-2 & Spring & 83 & Arg & Spring \\
\hline 38 & Mughan-3 & Spring & 84 & UN-11 & Winter \\
\hline 39 & Golestan & Spring & 85 & Kohdasht & Spring \\
\hline 40 & Alborz & Spring & 86 & Ohadi & Winter \\
\hline 41 & Kaveh & Facultative & 87 & Rijav & Facultative \\
\hline 42 & Rassoul & Spring & 88 & Rasad & Winter \\
\hline 43 & Tajan & Spring & 89 & Karim & Spring \\
\hline 44 & Shiroudi & Spring & 90 & $\mathrm{Ch}$ & Winter \\
\hline 45 & Darya & Spring & 91 & Homa & Winter \\
\hline 46 & Arta & Spring & 92 & Norstar & Winter \\
\hline
\end{tabular}


Table 2. Description of SSR markers employed in the study

\begin{tabular}{llcccccccc}
\hline No. & $\begin{array}{c}\text { Primer } \\
\text { name }\end{array}$ & $\begin{array}{c}\text { Annealing } \\
\text { Temperature }\end{array}$ & $\begin{array}{c}\text { No of } \\
\text { allele }\end{array}$ & PIC $^{\dagger}$ & No & $\begin{array}{c}\text { Primer } \\
\text { name }\end{array}$ & $\begin{array}{c}\text { Annealing } \\
\text { Temperature }\end{array}$ & $\begin{array}{c}\text { No of } \\
\text { allele }\end{array}$ & PIC $^{*}$ \\
\hline 1 & Xbarc13 & 60 & 2 & 0.73 & 21 & Xgwm304 & 55 & 2 & 0.72 \\
2 & Xbarc54 & 40 & 2 & 0.80 & 22 & Xgwm371 & 65 & 2 & 0.47 \\
3 & Xbarc61 & 52 & 2 & 0.42 & 23 & Xgwm382 & 66 & 2 & 0.65 \\
4 & Xbarc65 & 52 & 2 & 0.75 & 24 & Xgwm577 & 55 & 2 & 0.68 \\
5 & Xbarc86 & 68 & 2 & 0.52 & 25 & Xwmc52 & 61 & 2 & 0.55 \\
6 & Xbarc146 & 52 & 2 & 0.67 & 26 & Xwmc215 & 61 & 2 & 0.67 \\
7 & Xbarc148 & 60 & 2 & 0.12 & 27 & Xwmc317 & 55 & 2 & 0.57 \\
8 & Xbarc149 & 50 & 2 & 0.69 & 28 & Xwmc453 & 61 & 2 & 0.74 \\
9 & Xbarc164 & 58 & 2 & 0.68 & 29 & Xwmc596 & 60 & 2 & 0.60 \\
10 & Xbarc178 & 52 & 2 & 0.15 & 30 & Xwmc662 & 61 & 2 & 0.13 \\
11 & Xbarc200 & 52 & 2 & 0.79 & 31 & Xwmc722 & 50 & 2 & 0.60 \\
12 & Xbarc320 & 63 & 2 & 0.76 & 32 & Xcfd5 & 60 & 2 & 0.68 \\
13 & Xbarc352 & 60 & 2 & 0.76 & 33 & Xcfd13 & 60 & 2 & 0.68 \\
14 & Xbarc1060 & 55 & 2 & 0.17 & 34 & Xcfd18 & 60 & 2 & 0.69 \\
15 & Xgwm5 & 62 & 2 & 0.63 & 35 & Xcfd40 & 60 & 2 & 0.46 \\
16 & Xgwm513 & 60 & 2 & 0.75 & 36 & Xcfd42 & 66 & 2 & 0.68 \\
17 & Xgwm257 & 60 & 2 & 0.76 & 37 & Xcfd59 & 60 & 2 & 0.58 \\
18 & Xgwm261 & 59 & 2 & 0.67 & 38 & Xcfa2141 & 60 & 2 & 0.48 \\
19 & Xgwm272 & 50 & 2 & 0.45 & 39 & Xcfa2153 & 59 & 2 & 0.74 \\
20 & Xgwm285 & 60 & 2 & 0.75 & 40 & Xcfa2164 & 60 & 2 & 0.55 \\
\hline & Total & & 40 & & & Total & & 40 & 2 \\
& Mean & & 2 & & & Mean & & \\
\hline
\end{tabular}

${ }^{\dagger}$ Polymorphism information content

\subsection{Cluster Analysis}

Genetic similarity values among cultivars ranged from 0.17 to 0.88 . The lowest and highest genetic similarity was observed between the 'Mihan' and 'Star' (No. 31 and 57), 'Azadi' and 'Mahdavi' (No 4 and 6) cultivars, respectively. To present the genetic relationship among 92 wheat cultivars, a dendrogram was constructed (Figure 1). If the cutting is done on the $53 \%$ similarity coefficient, cultivars could be divided into six major groups. Cluster I included 14 cultivars, cultivars under study had three growth types: spring, winter and facultative, maximum genetic similarity value (0.61) in this group was observed between Sardari (No. 70) and Azar-2 (No 71), that both are winter wheat. These cultivars are rainfed and suitable for planting in cold and moderate areas. Cluster II included 11 cultivars that all of them had spring growth type. Each of Clusters III and IV consisted of 20 cultivars. Cultivars that were grouped in cluster III have spring and winter growth types. Although these cultivars have different growth type as a single trait, these cultivars were not significantly different at the molecular level presented by SSR primers that are used in this study. In this cluster, the maximum genetic similarity was observed between Sistan and Kohdasht cultivars (No 82 and 90). The majority of cultivars that were grouped in cluster IV had spring growth type, among all of cultivars No 4 and 6 revealed a high degree of similarity (0.88) that is grouped in this cluster. Twenty and 7 Cultivars were grouped in cluster V and VI. The highest genetic similarity (0.73) inside the cluster V was related to Gaspard and Gascogene (No 25 and 26) that both are winter growth type French varieties. In cluster VI Shiroudi cultivar was grouped in a sub-cluster, this cultivar was less similar to the others that are grouped in this cluster. Maximum genetic similarity $(0.70)$ on this cluster was observed between MV-17 (No 24) and Pishgam (No 30) cultivars, that they are winter and facultative growth type, respectively. Although SSR or microsatellite markers are often of multi-allelic nature, co-dominant inheritance, relative abundance, and extensive genome coverage were observed (Gupta \& Varshney, 2000). Microsatellite markers are 
useful and becoming popular for different applications in wheat breeding due to their high level of polymorphism and easy handling (Devos et al., 1995; Roder et al., 1995; Bryan et al., 1997; Roy et al., 1999; Lelley et al., 2000) and are used to evaluate genetic diversity of hexaploid wheat (Al Khanjari et al., 2007). In the present study SSR markers almost succeeded in discrimination wheat cultivars. But these markers could not separate wheat cultivars with different growth types completely. One reason could be that these cultivars had similar genetic resource, in addition that wheat is a self-pollinated crop and it has a narrow genetic base. Most of the primers that have been used in this study revealed a high polymorphism. So they can be used for screening, evaluation of genetic diversity and molecular mapping studies in bread wheat. In general, diversity measurements were higher in the cultivars at which such a high level of genetic similarity may be used for selection of the materials in the breeding programs where cultivars with high genetic distance can be used for this purpose. It can be concluded that more polymorphic wheat SSR markers could be used for efficient screening of the germplasm by saturating more regions of wheat genome.

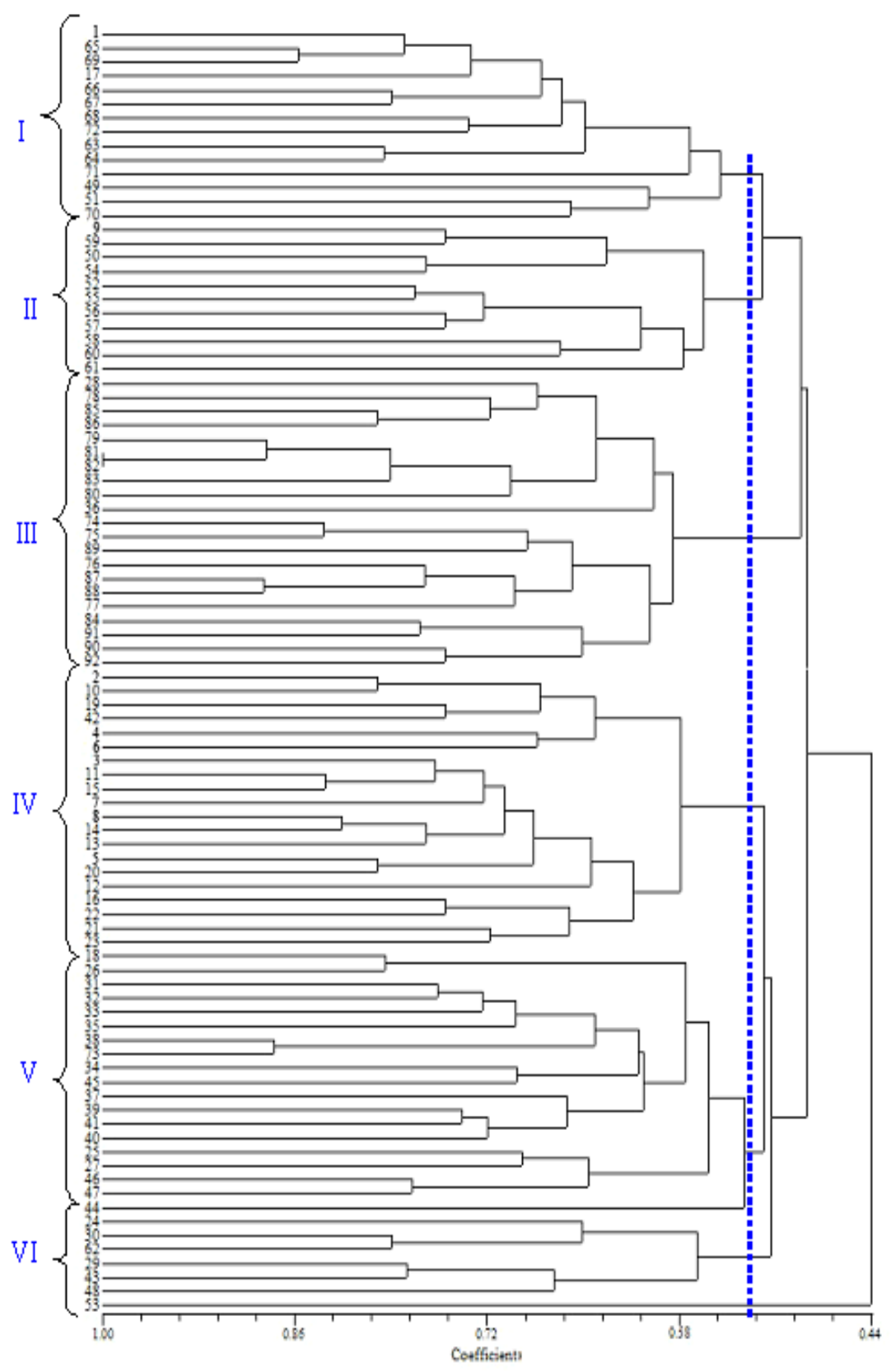

Figure 1. Dendrogram from UPGMA analysis based on Jaccard similarity coefficient of 92 bread wheat cultivars (No. 1-92 names of wheat cultivars according to Table 1) 


\section{Conclusion}

In the present investigation, SSR markers showed a high level of polymorphism and considered as enough informative in hexaploid wheat. The genetic diversity levels observed in bread wheat's that are cultivated in Iran would be useful indicators if such an approach is planned for the wheat genome. This makes genomic diversity estimates a potentially valuable predicting source for selecting diverse parent genotypes for favorable heterotic combinations in wheat improvement program.

\section{Acknowledgements}

We thank Seed and Plant Improvement Institute, Karaj, Iran, for providing the seed materials. We also gratefully acknowledge to E and A. Salahvarzi, Z. Foladvand and A. mirazadi for many helpful comments and suggestions.

\section{References}

Akkaya, M. S., \& Buyukunal-Bal, E. B. (2004). Assessment of genetic variation of bread wheat varieties using microsatellite markers. Euphytica, 135, 179-185. http://dx.doi.org/10.1023/B:EUPH.0000014908.02499.41

Al Khanjari, S., Hammer, K., Buerkert, A., \& Roder, M. S. (2007). Molecular diversity of Omani wheat revealed by microsatellites. Genetic Resource and Crop Evolution, 54, 1407-1417. http://dx.doi.org/10.1007/s10722-006-9125-1

Altintas, S., Toklu, F., Kafkas, S., Kilian, B., Brandolini, A., \& Ozkan, H. (2008). Estimating Genetic Diversity in Durum and Bread Wheat Cultivars from Turkey using AFLP and SAMPL Markers. Plant Breeding, 127, $9-14$.

Anderson, J. A., Churchill, G. A., Autrique, J. E., Tanksley, S. D., \& Sorrells, M. E. (1993). Optimization parental selection for genetic linkage maps. Genome, 36, 181-186. http://dx.doi.org/10.1139/g93-024

Botstein, D., White, R. L., Skolnick, M., \& Davis, R. W. (1980). Construction of a Genetic Linkage Map in Man Using Restriction Fragment Length Polymorphisms. American Journal of Human Genetics, 32, 314-331.

Bryan, G. J., Collins, A. J., Stephenson, P., Orry, A., Smith, J. B., \& Gale, M. D. (1997). Isolation and characterization of microsatellites from hexaploid bread wheat. Theoretical and Applied Genetics, 94, 557-563. http://dx.doi.org/10.1007/s001220050451

Chao, S., Zhang, W., Dubcovsky, J., \& Sorrells, M. (2007). Evaluation of Genetic Diversity and Genome-wide Linkage Disequilibrium among U.S. Wheat (Triticum aestivum L.) Germplasm Representing Different Market Classes. Crop Sci., 47, 1018-1030.

Devos, K. M., Bryan, G. J., Collins, A. J., \& Stephenson, P. (1995). Application of two microsatellite sequences in wheat storage proteins as molecular markers. Theoretical and Applied Genetics, 90, 247-252. http://dx.doi.org/10.1007/BF00222209

Eivazi, A. R., Naghavi, M. R., Hajheidari, M., Pirseyedi, S. M., Ghaffari, M. R., Mohammadi, S. A., .. Mardi, M. (2008). Assessing wheat (Triticum aestivum L.) genetic diversity using quality traits, amplified fragment length polymorphisms, simple sequence repeats and proteome analysis. Annals of Applied Biology, 152, 81-91. http://dx.doi.org/10.1111/j.1744-7348.2007.00201.x

Frankel, O. H., \& Bennett, E. (1970). Genetic resources in plants-their exploration and conservation. Davis FA. Philadelphia, USA.

Fufa, H., Baenziger, P. S., Beecher, B. S., Dweikat, I., Graybosch, R. A., \& Eskridge, K. M. (2005). Comparison of phenotypic and molecular marker-based classifications of hard red winter wheat cultivars. Euphytica, 145, 133-146. http://dx.doi.org/10.1007/s10681-005-0626-3

Gupta, P. K., Balyan, H. S., Sharma, P. C., \& Ramesh, B. (1996). Microsatellites in plants: a new class of molecular markers. Current Science, 70, 45-54.

Gupta, K., Balyan, S., Edwards, J., Isaac, P., Korzun, V., Roder, M., ... Leroy, P. (2002). Genetic mapping of 66 new microsatellite (SSR) loci in bread wheat. Theoretical and Applied Genetics, 105, 413-422. http://dx.doi.org/10.1007/s00122-002-0865-9

Gupta, P. K., \& Varshnei, R. K. (2000). The development and use of microsatellite markers for genetic analysis and plant breeding with emphasis on bread wheat. Euphytica, 113, 163-185. http://dx.doi.org/10.1023/A:1003910819967

Guyomarch, H. (2002). Characterization of polymorphic microsatellite markers from Aegilops tauschii and transferability to the D-genome of bread wheat. Theoretical and Applied Genetics, 104, 1164-1172. 
Hai, L., Wagner, C., \& Friedt, W. (2007). Quantitative structure analysis of genetic diversity among spring bread wheats (Triticum aestivum L.) from different geographical regions. Genetica, 130, 213-225. http://dx.doi.org/10.1007/s10709-006-9008-6

Ijaz, S., \& Khan, I. A. (2009). Molecular characterization of wheat germplasm using microsatellite markers. Genetics and Molecular Research, 8(3), 809-815. http://dx.doi.org/10.4238/vol8-3gmr608

Jaccard, P. (1908). Nouvelles recherches sur la distribution florale. Bulletin Society Vaud Science National, 44, 223-270.

Landjeva1, S., Korzun, V., \& Ganeva1, G. (2006). Evaluation of genetic diversity among Bulgarian winter wheat (Triticum aestivum L.) varieties during the period 1925-2003 using microsatellites. Genetic Resources and Crop Evolution, 53, 1605-1614.

Lelley, T., Stachel, M., Grausgruber, H., \& Vollmann, J. (2000). Analysis of relationships between Aegilops tauschii and the D genome of wheat utilizing microsatellites. Genome, 43, 661-668.

Mahmood, A., Baenziger, P. S., Budak, H., Gill, K. S., \& Dweikat, I. (2004). The use of microsatellite markers for the detection of genetic similarity among winter bread wheat lines for chromosome 3A. Theoretical and Applied Genetics, 109, 1494-1503. http://dx.doi.org/10.1007/s00122-004-1766

Manifesto, M. M., Schlatter, A. R., Hopp, H. E., Suarez, E. Y., \& Dubcovsky, J. (2001). Quantitative evaluation of genetic diversity in wheat germplasm using molecular markers. Crop Sci, 41, 682-690. http://dx.doi.org/10.2135/cropsci2001.413682x

Mohammadi, S. A., Khodarahmi, M., Jamalirad, S., \& Jalal Kamali, M. R. (2009). Genetic diversity in a collection of old and new bread wheat cultivars from Iran as revealed by simple sequence repeat-based analysis. Annals of Applied Biology, 154, (1), 67-76. http://dx.doi.org/10.1111/j.1744-7348.2008.00273.x

Parker, G. D., Fox, P. N., Langridge, P., Chalmers, K., Whan, B. , \& Ganter, P. F. (2002). Genetic diversity within Australian Wheat breeding programs based on molecular and pedigree data. Euphytica, 124, 293-306. http://dx.doi.org/10.1023/A:1015725522441

Prasad, M., Varshney, R. K., Roy, J. K., Balyan, H. S., \& Gupta, P. K. (2000). The use of microsatellites for detecting DNA polymorphism, genotype identification and genetic diversity in wheat. Theoretical and Applied Genetics, 100, 584-592.

Prasad, B., Babar, M. A., Xu, X. Y., Bai, G. H., \& Klatt, A. R. (2009). Genetic diversity in the U.S. hard red winter wheat cultivars as revealed by microsatellite markers. Crop \& Pasture Science, 60, 16-24 http://dx.doi.org/10.1071/CP08052

Roder, M. S., Plaschke, J., Konig, S. U, Borner, A., Sorrells, M. E, \& Tanksley, S. D. (1995). Abundance variability and chromosomal location of microsatellite in wheat. Molecular Genetics and Genomics, 246, 327-333. http://dx.doi.org/10.1007/BF00288605

Roder, M. S., Korsun, V., Wendehake, K., Plaschke, J., Tixier, M. H., Leroy, P., \& Ganal, M. W. (1998). A microsatellite map of wheat. Genetics, 149, 2007-2023.

Rohlf, F. J. (1992). NTSYS-pc: numerical taxonomy and multivariate analysis system. New York: Exeter Software. Retrieved from http:/www.exetersoftware.com

Roussel, V., Koenig, J., Beckert, M., \& Balfourier, F. (2004). Molecular diversity in French bread wheat accessions related to temporal trends and breeding programs. Theoretical and Applied Genetics, 108, 920-930. http://dx.doi.org/10.1007/s00122-003-1502-y

Roy, J. K., Prasad, M., Varshney, R. K., \& Balyan, H. S. (1999). Identification of a microsatellite on chromosomes 6B and a STS on 7D of bread wheat showing an association with preharvest sprouting tolerance. Theoretical and Applied Genetics, 99, 336-340. http://dx.doi.org/10.1007/s001220051241

Salem, K. F. M., El-Zanaty, A. M. \& Esmail, R. M. (2008). Assessing wheat (Triticum aestivum L.) genetic diversity using morphological characters and microsatellite markers. World Journal of Agricultural Science, 4(5), 538-544.

Song, Q. J., Shi, J. R., Singh, S., Fickus, E. W., Costa, J. M., Lewis, J., .. Cregan, P. B. (2005). Development and mapping of microsatellite (SSR) markers in wheat. Theoretical and Applied Genetics, 110, 550-560. http://dx.doi.org/10.1007/s00122-004-1871-x 
Sourdille, P. (2001). Improvement of the genetic maps of wheat using new microsatellite markers Plant and Animal Genome IX Abstracts 167.

Stachel, M., Lelley, T., Grausgrube, H., \& Vollmann, J. (2000). Application of microsatellites in wheat (Triticum aestivum L.) for studying genetic differentiation caused by selection for adaptation and use. Theoretical and Applied Genetics, 100, 242-248. http://dx.doi.org/10.1007/s001220050032

Tautz, D., Renz, M. (1989). Hypervariability of simple sequences as general source of ploymorphic DNA markers. Nucleic Acids Research, 17, 6463-6471. http://dx.doi.org/10.1093/nar/17.16.6463 